\title{
LARGE HAIL IN POLAND IN 2012
}

\author{
Mateusz Taszarek, Katarzyna SuWaŁa
}

Institute of Physical Geography and Environmental Planning, Adam Mickiewicz University in Poznań, Poland

Manuscript received: 17 January, 2014

Revised version: 31 December, 2014

Taszarek M., SuwaŁa K., 2013. Large hail in Poland in 2012. Quaestiones Geographicae 34(1), Bogucki Wydawnictwo Naukowe, Poznań, pp. 75-84, 8 figs. DOI 10.1515/quageo-2015-0007, ISSN 0137-477X

\begin{abstract}
AвsTRACT: This report analyses significant hailstorms that occurred in Poland during 2012. The number of reports, derived from the European Severe Weather Database with the hail diameter over or equal $2 \mathrm{~cm}$, were analyzed with respect to their frequency in individual months, time of the day, intensity and spatial distribution. Analyzed cases were divided for hail with diameter less than $4 \mathrm{~cm}$ and greater or equal $4 \mathrm{~cm}$. Accompanying conditions were examined by synoptic analysis charts derived from Deutscher Wetterdienst. The total number of 121 large hail cases gave 26 days with this phenomenon. The period of their occurrence extended from April to August reaching peak in July. Above $60 \%$ of all events were reported between 1500 and 1800 UTC. Most of them were associated with cold front and squall line features, usually with the south-western warm and moist air mass influx.
\end{abstract}

KEY WORDS: large hail, thunderstorm, severe weather, Poland, 2012

Address of the corresponding author: Mateusz Taszarek, Institute of Physical Geography and Environmental Planning, Adam Mickiewicz University in Poznań, Poznań, Poland; e-mail: tornado@amu.edu.pl

\section{Introduction}

According to some previous IPCC reports (Folland et al. 2001), small-scale severe weather phenomena (SCSWP), such as tornadoes and hailstorms, which are often described as quasi-random temporal and spatial events, may cause significant damage to agriculture, infrastructure and generate a threat to human life. Owing to the growing frequency of extreme weather events, recently more attention in atmospheric studies is devoted to the analysis of these particular weather phenomena. Although the public often mistakenly associate very large hail only with the areas of the Great Plains in the Northern America, recently in Poland there is a significant growth in people's severe weather awareness that these kind of phenomena are also possible in Europe and thus Poland. The variability of the weather in Europe along with the moderate climate and diversified landscape where marine and continen- tal airmasses mix, may favor the development of destructive weather phenomena (Koźmiński 1964). The example of the year in which extreme weather events, particularly large hail, were relatively frequently reported in Poland was the year 2012. For this reason the authors decided to analyze the occurrence of hailstorms in Poland during that particular period of time.

Hail is a common hydrometeor which often accompanies thunderstorm cumulonimbus clouds. The larger the hailstones, the more significant damage can be reported. However, the maximum hailstone size does not always correspond to the severity of the hailstorms as there are other significant aspects such as intensity of the precipitation and its duration. Among the atmospheric factors that may lead to hail formation, we can distinguish: large updraft vertical velocity (so that the updraft can sustain the mass of the hailstones), high liquid water content (to "feed" the hail accretion), long storm duration with separa- 
tion of the updrafts and downdrafts (occurrence of the supercell; Browning 1964) and low height of the freezing level (shorter way to overcome by the falling hailstone). Large hail occurrence is local and its reporting is highly dependent whether it causes damage to property, thus making its analysis difficult. Kunz et al. (2009) claims a way to overcome this problem by linking the thunderstorms (along with hailstorms) to synoptic-scale or mesoscale atmospheric conditions, which can be calculated both from observational and forecast data derived from the numerical weather prediction models. As hail formation requires strong convection development and separation of downdrafts and updrafts, some instability indices such as Lifted Index (the difference between environmental temperature and lifted parcel's temperature at $500 \mathrm{hPa}$; Galway 1956) and CAPE (Convective Available Potential Energy, the amount of energy a parcel of air would have if lifted a certain distance vertically through the atmosphere; Miller 1967), moisture content parameter such as average mixing ratio in the lowest $500 \mathrm{~m}$ above the ground level (AGL), and kinematic parameters such as $0-6 \mathrm{~km}$ wind shear (the difference between wind magnitude at $2 \mathrm{~m}$ and 6 $\mathrm{km}$ AGL) and 0-3 km storm relative helicity (increases when vertical wind profile veers together with increasing vertical wind shear, see Hart and Korotky 1991 for more details) may appear useful in distinguishing environments conductive for producing the large hail (Groenemeijer and van Delden 2007, Sioutas and Flocas 2003). Since large hail occurs locally, there is a high chance that due to the insufficient number of meteorological stations and severe weather spotters it might be not reported, making climatological analysis difficult and incomplete. On the other hand, most of the severe hailstorms usually make serious damage to property, therefore it is easy to identify them in the media reports.

The most comprehensive studies on the hailstorms in Poland covered the period of the time before the year 1970 (Zinkiewicz and Michna 1955, Koźmiński 1964). It was an effect of large scale research on the reduction of damage to agriculture and private property caused by the large hail. Since then, less attention has been devoted to this phenomenon until the beginning of the XXI century when the soundings and numerical modeling data became widely available and numerous severe weather databases were established.

In recent studies, the general characteristics of the hail occurrence in Europe have been presented in spatial and temporal variability with a few case studies on the most severe events (Kunz et al. 2009, Bielec-Bąkowska 2010). Southern and northern parts of Europe were more thoroughly examined with respect to hail, giving a comprehensive picture of its occurrence, usually considering synoptic factors (Sioutas and Flocas 2003, Sioutas et al. 2009, Tuovinen at al. 2009). The climatological approach to the subject of hail forecasting becomes less useful as the analyses of convective parameters and atmospheric soundings gained more popularity and became more effective in forecasting severe weather phenomena (Craven and Brooks 2004, Groenemeijer and van Delden 2007). Although this study is limited only to one year, it is worth mentioning that not many studies in Poland have been devoted to analyze in particular large hail phenomena and case study of the most severe events.

The purpose of this paper was to analyze the spatial and temporal variability of large hail in Poland during the year 2012 and distinguish synoptic conditions during hailstorm days, with more detailed examination of selected extreme hailstorm event. Firstly, the occurrence of large hail in chosen year was given as the spatial, seasonal and diurnal distribution was examined. Secondly, synoptic analysis chart, $500 \mathrm{hPa}$ geopotential map and chosen convective indices derived from atmospheric sounding were used to investigate conditions responsible for severe hailstorms on $3^{\text {rd }}$ July 2012.

\section{Dataset and methods}

In this paper the term of hailstorm will refer to the reported large hail on the ground. In order to achieve the aim of the study, significant hailstorm reports from year 2012 reported in the European Severe Weather Database (ESWD; Groenemeijer et al. 2004, Dotzek et al. 2009) were collected. Only verified reports with status QC1 (report confirmed) and QC2 (event fully verified) were taken into account. These reports have been mainly submitted by witnesses of the hailstorms and were often supported by the photography of 
the hailstones. However, since any citizen and not officially trained observers can submit this information to ESWD we have to take into account that the accuracy of measuring the size of the hail may be inaccurate in many cases. If hailstones were not measured, their size was estimated on the basis of object-to-size conversion of wellknown objects like e.g. ping pong, golf ball, hen egg, tennis ball. Obtained hail cases have been analyzed in the context of their intensity and spatial and time distribution of their occurrence. The analysis assumed: hail frequency in individual months (measured by the number of days with large hail), time of the day (measured by the number of reported cases), spatial distribution of reports and intensity measured by the diameter of the hailstone. All cases have been divided into smaller than $4 \mathrm{~cm}$ and larger or equal $4 \mathrm{~cm}$ hailstone groups. It is worth mentioning that only the longest possible diameter of the hailstone have been taken into consideration. As this paper is related to significant hail analysis, only reports with largest hail diameter equal to or greater than $2 \mathrm{~cm}$ were the subject of this study. Synoptic-scale conditions were taken from Deutscher Wetterdienst (DWD) synoptic charts. Air mass advection direction measured at the $500 \mathrm{hPa}$ pressure level have been taken from 1200UTC soundings from Legionowo. In addition, in the most severe case from $3^{\text {rd }}$ July, accompanying synoptic conditions and sounding-derived parameters were also analyzed. Synoptic analysis chart was created on the

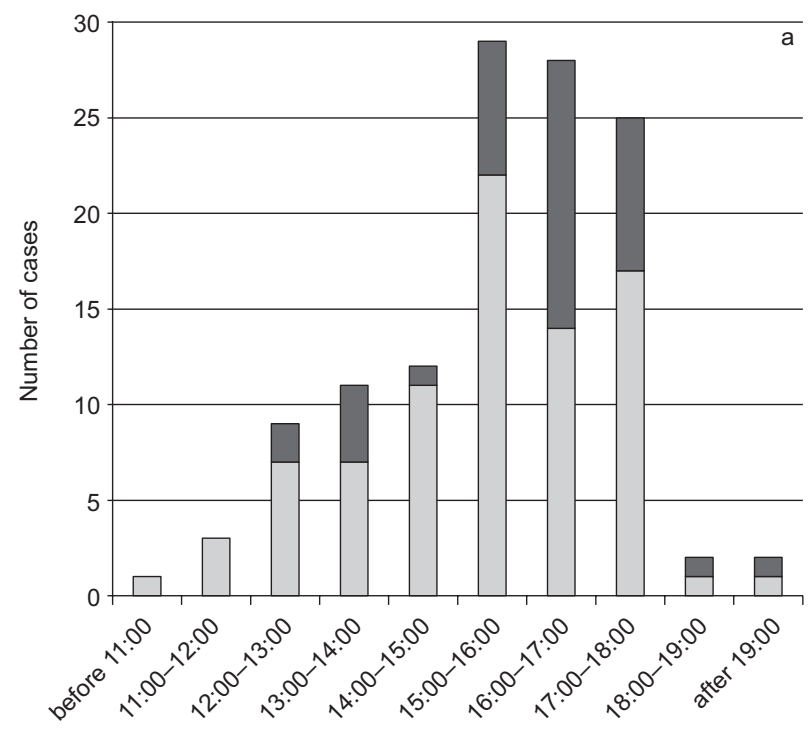

basis of DWD chart data while $500 \mathrm{hPa}$ geopotential map with surface sea level pressure was taken from GFS analysis (Global Forecast System model, wetter3.de archive). Sounding data from Legionowo 1200UTC was derived from Univeristy of Wyoming database (weather.uwyo.edu/ upperair/sounding) and plotted in the Skew-T chart. NOAA-15 AVHRR B4 polar satellite image on 3rd July 20121508 UTC derived from Czech Hydrometeorological Institute was also uded in the analysis.

\section{Results}

\section{Spatial and temporal variability of the hailstorms}

In 2012 according to ESWD Poland experienced 26 days with significant hail in which 121 hailstorms were reported. Most of them were reported in the beginning of July when Poland experienced numerous severe thunderstorms. Largest tennis ball-size hailstones $(\sim 7 \mathrm{~cm}$ in diameter) were reported on 03.07.2012 in the region of Czechowice-Dziedzice city around 1500 UTC. Period in which hailstorms were recorded in 2012 was extending from April to August, from 1030 UTC to 2100 UTC and one during the night. Hailstorms occurred in the one April day, five May days, three June days, eleven July days and six August days (Fig. 1b). Significant hail

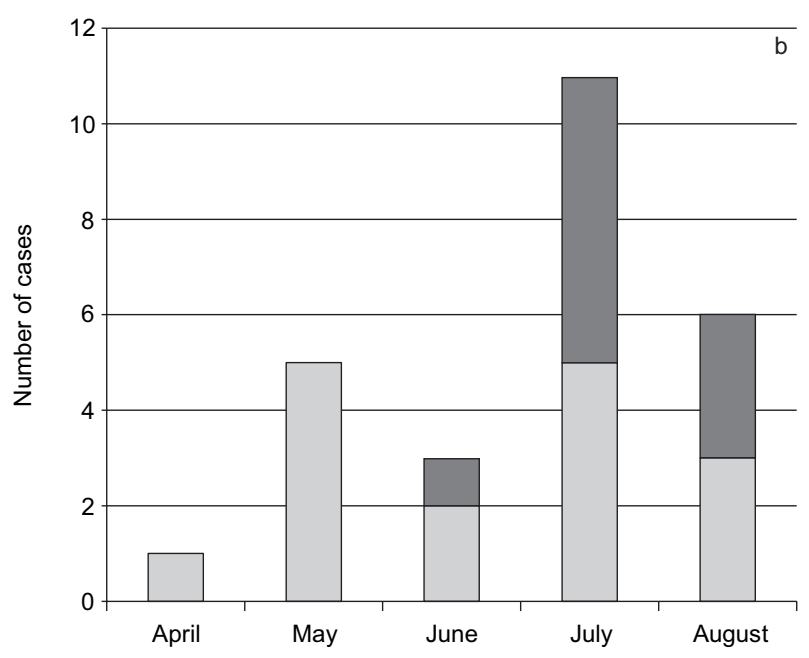

Fig. 1. Large hail in Poland observed in 2012 by a) - time (including all hail reports), and b) - month (including all hail days). Grey color indicate hailstones with diameter greater than $2 \mathrm{~cm}$ and less than $4 \mathrm{~cm}$. Black color indicate hailstones with diameter greater or equal $4 \mathrm{~cm}$ (based on reports from ESWD) 

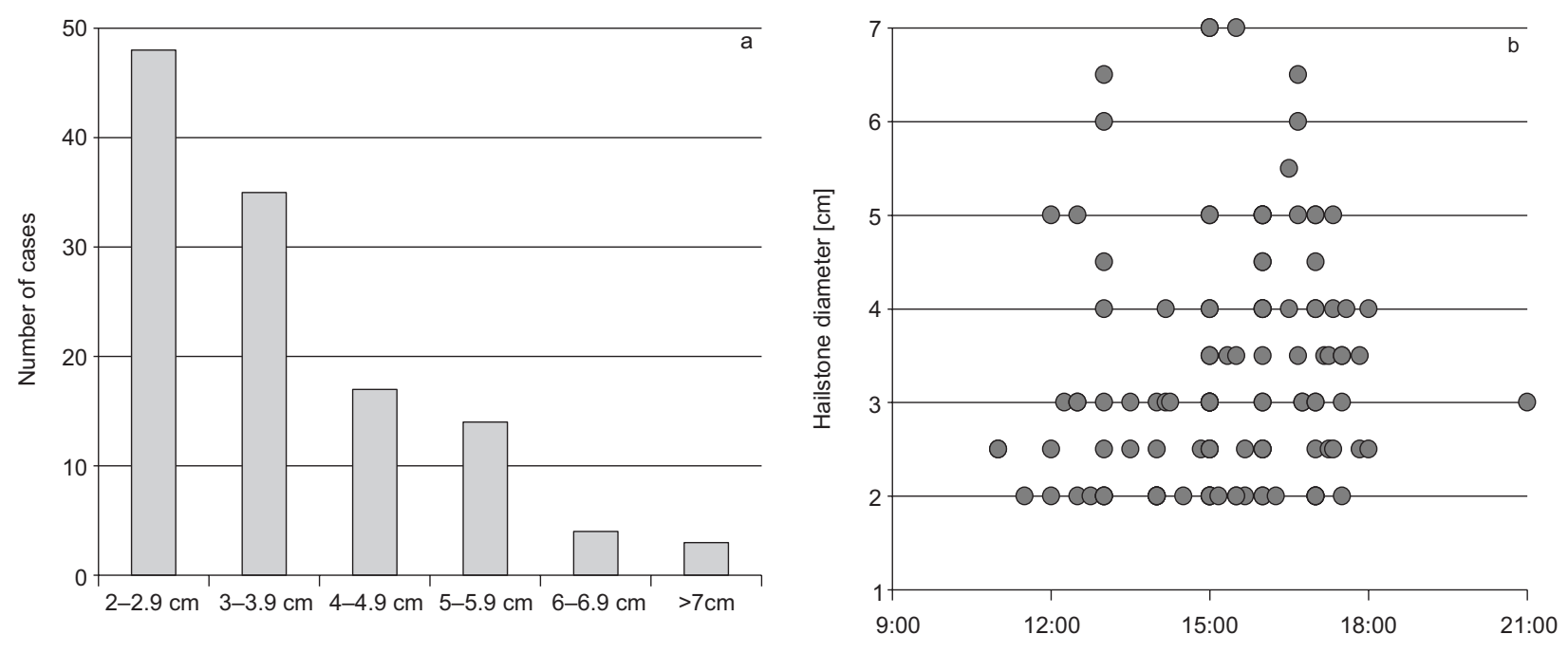

Fig. 2. Number of large hail reports in Poland in 2012 a) - measured by the hailstone diameter, and b) - examined on the scatterplot chart with hail diameter (y axis) and time of the day ( $\mathrm{x}$ axis), based on reports from ESWD

with the hailstones diameter greater or equal 4 $\mathrm{cm}$ were exclusively occurring in the summer months: June July and August with the highest activity attributable to July. During the day, their greatest activity was fairly well correlated with convective activity in afternoon hours and was extending from 1500 UTC up to 1800 UTC (Fig. 1b). Significant hail with less frequency also occurred before 1500 UTC but in the most cases was less severe. Hail with diameter larger or equal 4 $\mathrm{cm}$ was the most common in the hours between 1600 UTC and 1700 UTC. Due to the lack of the solar radiation and earth surface heating in the evening hours, thunderstorm activity and thus strong updrafts which are sustaining large hail (Knight and Knight 2001) are weakening and therefore occurrence of large hail after 1800 UCT becomes marginal.

Distribution of the hail reports depending on their intensity measured by the hail diameter was presented in the figure 2a. Frequency of the reports decreases proportionally with the increasing hail size. In analyzed year, almost $70 \%$ cases of the significant hailstorms produced hailstones ranging between $2-4 \mathrm{~cm}$ in diameter. Hailstones with size from $4 \mathrm{~cm}$ up to $6 \mathrm{~cm}$ were represented by $25 \%$ of all analyzed cases. Last group with the largest hailstones, larger than $6 \mathrm{~cm}$ occurred only in $5 \%$ of all reported significant hailstorms. Relationship between time of the event and hail size was examined on the scatterplot in the figure $2 b$. Severity of hailstorms increases proportionally to the time of the day and around 1500-1700 UTC reaches maximum values, then potential for large hail decreases. Explanation for this can be related to high CAPE values which are usually the highest in these hours (due to the highest daily values of the surface temperatures and dew point temperatures). However, some cases of very large hail were also reported around 1300 UTC. According to the mechanism of the hail creation, it is also known that supercells (Browning 1964) which form under special conditions (combination of instability and strong wind shear) are conducive in producing severe weather and especially very large hail. Since tilted and separated strong updrafts and downdrafts in the supercells provide numerous hail-cycles, hailstones have sufficient conditions to reach very large size (Knight and Knight 2001).

Spatial distribution of all cases have been presented in the figure 3. Grey triangles denote significant hail reports with diameter below $4 \mathrm{~cm}$ while black triangles denote significant hail with diameter above or equal $4 \mathrm{~cm}$. As it can be seen, most of the hailstorms occurred in the southern and eastern part of the Poland while north-western part with coastal area experienced almost no significant hail. It can be concluded that significant hailstorms were generally reported in the highland areas of the country (Silesian Highland, Małopolska Highland, Lubelska Highland and Białostocka Highland) and also Mazurskie Lakeland. This can be explained by the higher terrain elevation which shortens the distance of the falling hailstone and reduces ice melting ratio providing that larger hailstones reach the earth surface. Since eastern and southern parts of Po- 


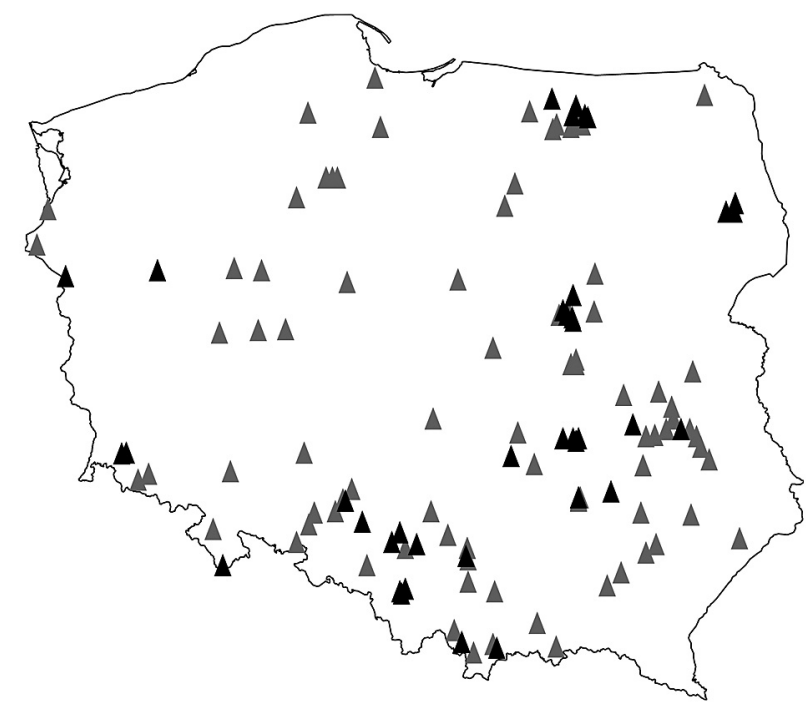

Fig. 3. Large hail in Poland reported in 2012, grey triangles denote hailstone with diameter less than $4 \mathrm{~cm}$, while black triangles denote hailstone with diameter greater or equal 4 $\mathrm{cm}$ (based on reports from ESWD)

land are more likely to produce thunderstorms (Bielec-Bąkowska 2002, Kolendowicz 2006), associated with them circulation patterns may also play an important role in spatial distribution of the significant hailstorms

\section{Synoptic conditions}

Selected parameters connected with synoptic situation in the large hail days are presented in the figure 4 . Analyzing data it can be concluded that the most of the large hail events (and the most destructive) occurred in the cold fronts (41\% cases) and the squall lines (identified on the radar data) in the low's warm sector in the most cases in front of the approaching cold front $(26 \%$ cases), while $22 \%$ were observed in the zone of waved front where percentage of hailstones with diameter over $4 \mathrm{~cm}$ was lower. Internal storms (not associated with atmospheric fronts and occurring in the uniform air mass, usually tropical) produced large hail in $11 \%$ cases, in which hail diameter did not exceed $4 \mathrm{~cm}$. In addition it is worth to say that the large hail cases were not reported in warm and occlusion fronts. Such a distribution may find its explanation in the mechanism of the hail creation. As Knight and Knight (2001) suggest, size of the hail is related to liquid water content above freezing level and time spent in the updraft, and thus the storm lifecycle. Most buoyant atmosphere with high CAPE and

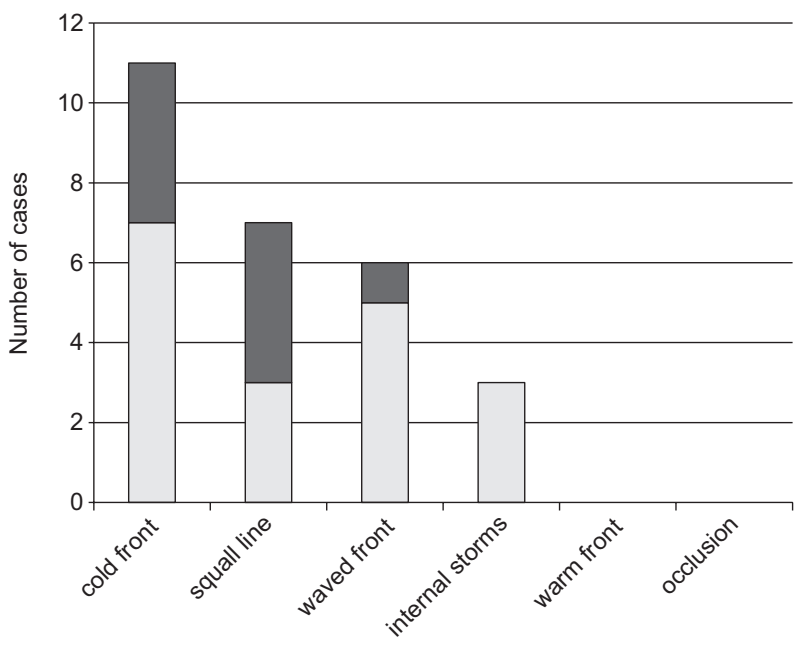

Fig. 4. Synoptic situation types in the days when large hail in 2012 in Poland was reported. Grey color indicate hailstones with diameter greater than $2 \mathrm{~cm}$ and less than $4 \mathrm{~cm}$ while black color indicate hailstones with diameter greater or equal $4 \mathrm{~cm}$ (based on reports from ESWD)

strong updrafts can be found in the cold fronts where moist and warm air is forced to lift, as well as in front of the fast moving cold fronts where instability can be extremely high (unstable air in warm sector of the synoptic low). Warm and rich in moisture air which is the sort of a "fuel" for the hailstones occurs during summer months, therefore in this period the largest hailstones were recorded (Fig. 1b). Also the influence of the wind shear can affect hail size (Dessens 1960, Groene-

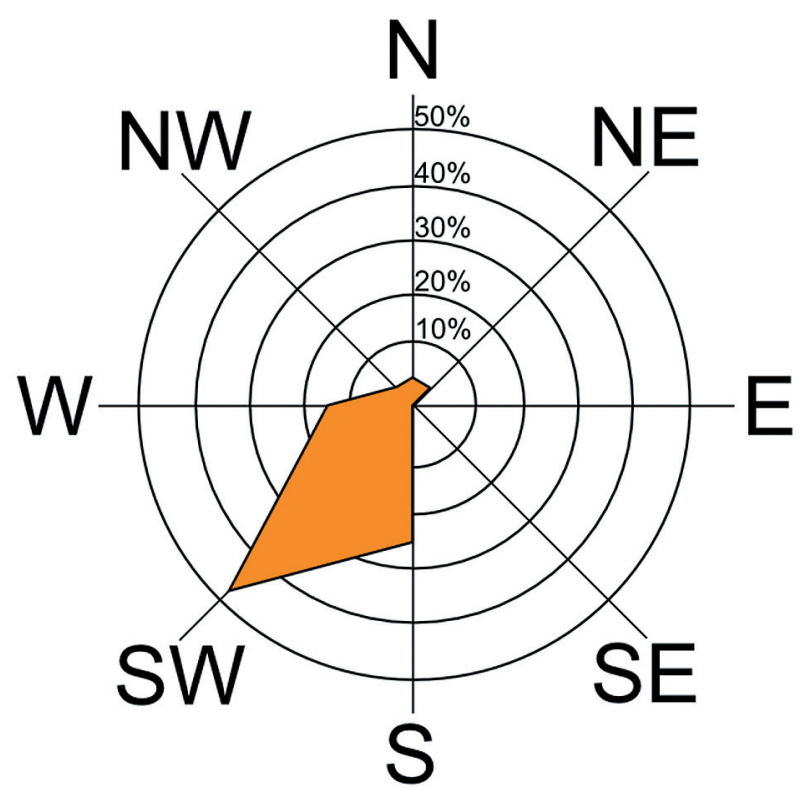

Fig. 5. Air mass advection direction measured at the 500 $\mathrm{hPa}$ level during days when the large hail in 2012 in Poland was reported (based on reports from ESWD and soundings from Legionowo 12UTC) 

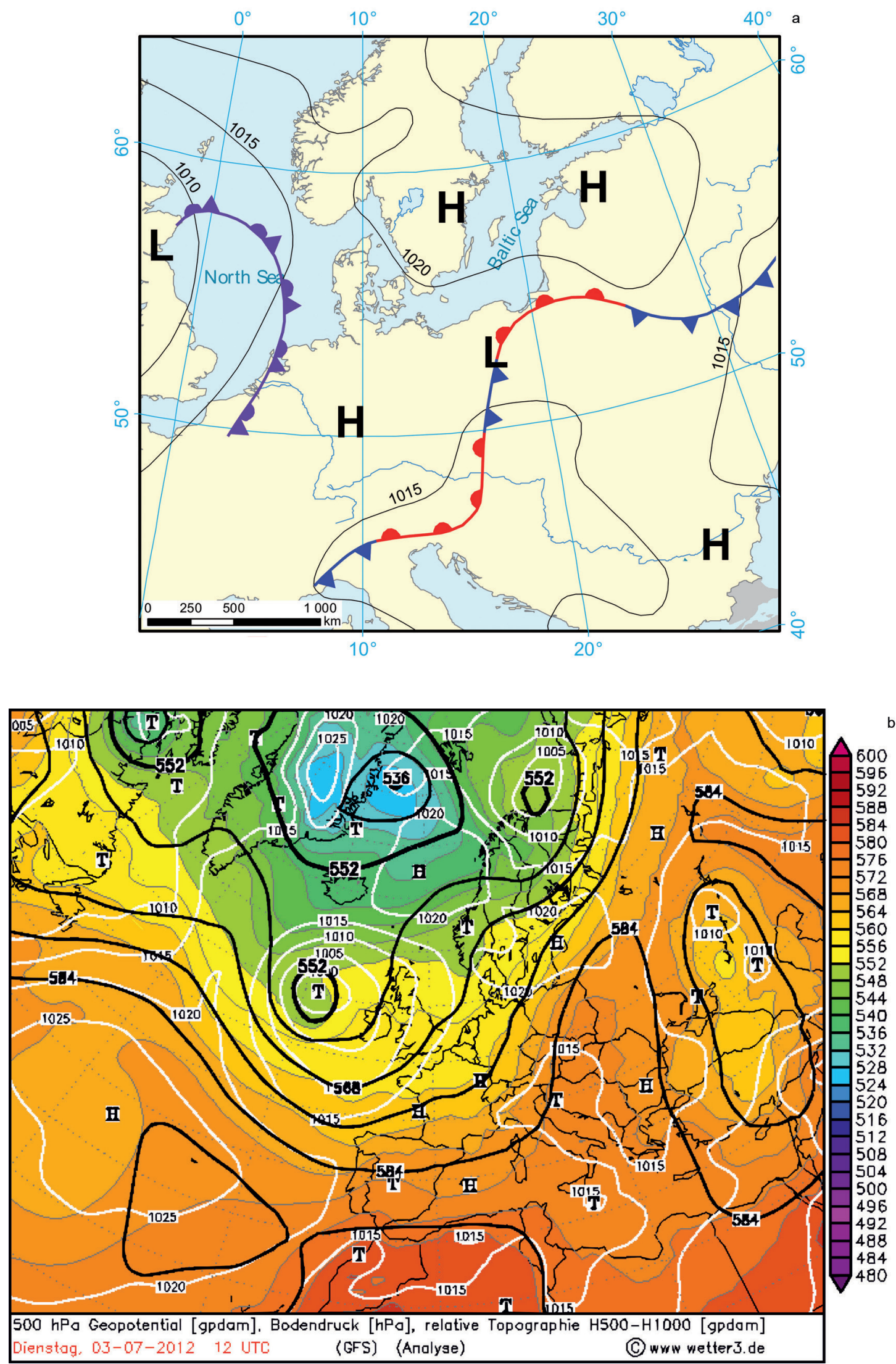

Fig. 6. Synoptic situation on 3rd July 2012 at 12 UTC

a) - analysis chart created on the basis of Deutscher Wetterdienst data, b) - $500 \mathrm{hPa}$ geopotential and surface pressure field (courtesy of wetter3.de) 
meijer and van Delden 2007). Storms that develop in moderate and high wind shear environments tend to organize in multicellular (also as squall lines) and supercellular structures where strong updrafts can be maintained longer and thus produce very large hail. In single cell storms like in the internal storms, where vertical wind shear is usually low, updrafts and downdrafts may be not enough organized to sustain the mass of the large hail.

As we can see in the figure 5, dominant direction of air mass advection measured at $500 \mathrm{hPa}$ pressure level (mostly used by meteorologists in defining weather circulation) in days when large hail was reported was SW (48\%) and S $(25 \%)$. West direction was represented by $14 \%$ of the cases while northern and eastern were almost marginal. Advection from SW and S direction during summer months is mostly related to warm, moist, and highly unstable air mass which usually during summer tend to produce severe thunderstorms in Poland. These synoptic situations conductive to the thunderstorms were described by Bielec-Bąkowska (2002), Kolendowicz (2006) and particularly for hail by Suwała (2012).

According to the whole 2012 year thunderstorms on the $3^{\text {rd }}$ of July 2012 were the most intense in producing the large hail in Poland. On that day Poland was under influence of blurred pressure field with waved front (Fig. 6a) dividing warm moist air masses of tropical origin (east part of Poland), and cooler air masses of polar origin (west part of Poland). The short wave on the cold front which occurred the day before, provided maintenance of warm air masses in southern and eastern parts of Poland pushing them towards the north (maximum 1500UTC temperature derived from SYNOP report in Rzeszów $34^{\circ} \mathrm{C}$ with dew point $19^{\circ} \mathrm{C}$ ). Cold front which was a result of the wave, brought cooler by approximately $12^{\circ} \mathrm{C}$ (based on the temperature difference in SYNOP reports from Rzeszów and Zielona Góra) polar air masses from western directions. In the meantime, the upper troposphere was experiencing the wide baric wave with an increased air flow set into SW-NE direction (Fig. 6b).

Sounding-derived parameters obtained in the Legionowo at 1200 UTC pointed presence of the highly unstable atmosphere (Fig. 7). Thermodynamic instability represented by CAPE index $\left(2880 \mathrm{~J} \mathrm{~kg}^{-1}\right)$ and Lifted Index $\left(-8,34^{\circ} \mathrm{C}\right)$ posed a high risk of severe thunderstorms with favorable conditions for the large hail. Measured deep layer wind shear (wind speed difference between surface and $6 \mathrm{~km}$ above the ground level, see Groenemeijer and van Delden 2007) was not significant $\left(15 \mathrm{~m} \mathrm{~s}^{-1}\right)$, but together with increased $0-3 \mathrm{~km}$ storm relative helicity $\left(128 \mathrm{~m}^{2} \mathrm{~s}^{-2}\right)$ could tend to separate updrafts and downdrafts in the convective cells. These kind of separation linked to supercells have been previously pointed by Doswell and Burgess (1993) as favorable for the large hail occurrence. Finally relaying on sounding data it can be concluded that moisture content in the thunderstorm environment was also large (precipitable water $38,7 \mathrm{~mm}$ ). Average mixing ratio from $0-500 \mathrm{~m}$ layer above the ground level amounted $14,4 \mathrm{~g} \mathrm{~kg}^{-1}$ and together with warm air was capped by dryer air mass in mid-level. This so called "loaded gun sounding" provides that if warm air has sufficient lifting forcing to overcome inversion, it usually "explodes" in afternoon hours and results in the severe convective thunderstorms. Severe weather threats found with these thunderstorms are: large hail, heavy precipitation, severe wind gusts and sometimes tornadoes (if the wind shear is large enough; Groenemeijer and van Delden 2007, Taszarek

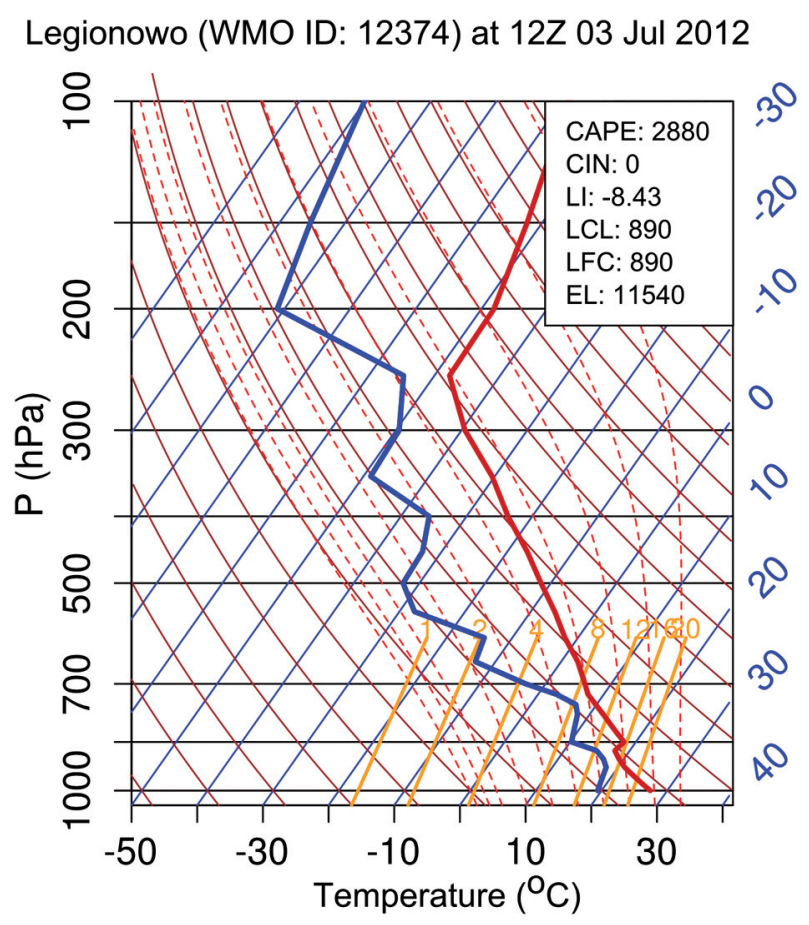

Fig. 7. Skew-T atmospheric sounding diagram derived from Legionowo station on 3rd July 20121200 UTC (based on University of Wyoming database raw sounding data) 

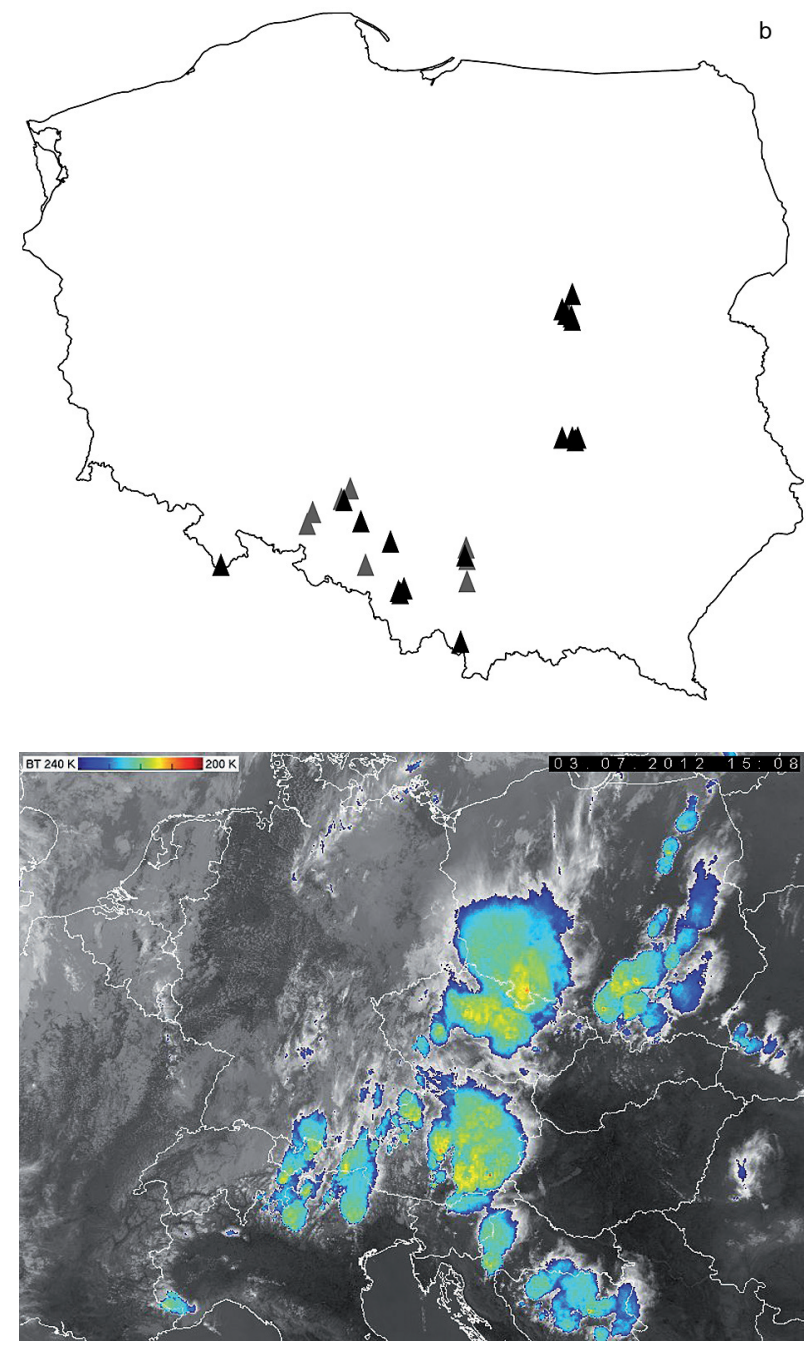

Fig. 8. a) - Large hail in Poland reported on 3rd July 2012, grey triangles denote hailstone with diameter less than 4 $\mathrm{cm}$, while black triangles denote hailstone with diameter greater or equal $4 \mathrm{~cm}$ (based on reports from ESWD), b) NOAA-15 AVHRR B4 polar satellite image on 3rd July 2012 1508 UTC (source: Czech Hydrometeorological Institute)

and Kolendowicz 2013). These kind of thunderstorms occurred in the warm sector of the synoptic low (in front of the cold front) in south-eastern Poland. Around 1200 UTC convection punched through inversion and resulted in few isolated thunderstorms which around 1600 UTC became severe and produced large hail (up to 6,5 $\mathrm{cm}$ ) with severe wind gusts. Another area where the large hail was reported was region of Silesia. These storms were associated with cold front and organized into Mesoscale Convective System (MCS; Morel and Sensei 2002, Cotton et al. 2003) which can be seen at the NOAA-15 AVHRR B4 polar satellite image in the figure $8 \mathrm{~b}$ (overshooting tops in the cloud system over southern Poland indicate strong convection punching the tropopause). This structure produced heavy precipitation, intense lightnings, severe wind gusts and numerous severe hailstorms (Fig. 8a). Largest tennis ball sized hailstones $(7 \mathrm{~cm})$ were found in Czechowice-Dziedzice, damage have been recorded to the agriculture, cars, infrastructure and forest. Arrival of the storm was preceded by the high temperature $\left(33^{\circ} \mathrm{C}\right)$ and humidity $\left(21^{\circ} \mathrm{C}\right.$ dew point). Storms vanished during the night in the eastern part of the country, but their highest severity fell between 1500 and 1800 UTC (on the basis of ESWD damage reports).

\section{Conclusions and discussion}

The motivation of this study was complex and divided into three sections. Firstly, the spatial and temporal (seasonal and diurnal) variability of the large hail in Poland during the year 2012 was analyzed. Secondly, the intensity of the hailstorms was described and finally, the synoptic conditions during the recorded hailstorm days and particularly the most severe case (distinguished on the basis of the hailstone size) was studied. Analysis revealed some features which can be summarized as follows:

During the year 2012, 121 large hail cases were reported, giving the total number of 26 days with the large hail. There is a difficulty in comparing these results with the other climatological studies, particularly due to the fact that the most hail studies include cases with all hail sizes and not only the large hail. In addition, they also analyze mostly data from meteorological stations and not from the severe weather spotters. The analysis of the severe hailstorms in northern Europe showed smaller frequency of severe hail than in Poland. During the last 70 years Tuovinen et al. (2009) distinguished approximately 10 days per year with sever hail in Finland and the maximum number of hail cases during the hail-peak year was 24.

Large hail season in 2012 started in April and ended in August reaching its peak in July when the most severe hailstorms were observed (hailstones diameter $\sim 7 \mathrm{~cm})$. Similar observations were made in Finland (Tuovinen at al. 2009) and the United States (Changon et al. 2009). The analyzed year differs from the recent studies on larger time intervals when hail in Poland occurred 
most often in May or June (Zinkiewicz and Michna 1955). However it has to be taken into account that this study focused only on the large hail reports while mentioned study analyzed the climatology of hail with all sizes.

Diurnal course of hail frequency indicate that the most favorable conditions for the large hail development are between 1500 and 1800 UTC (above $60 \%$ of large hail events), when the convection is the most intense. The severity of hailstorms reached its peak at about 1700 UTC. Changnon et al. (2009) proves that the temporal distribution of hail in the United States reflects the timing of the highest convective instability, which corresponds from 1500 to 1800 UTC. In comprehension, in Finland most severe hailstorms were recorded earlier between 1100 and 1300 UTC.

Previously, in the most pioneering hail studies in Poland (Zinkiewicz and Michna 1955, Koźmiński 1964), severe hail cases were accompanied by maximum $5 \mathrm{~cm}$ hailstones while in 2012 it sized up to $7 \mathrm{~cm}$ with almost 20 reports between 5 and $7 \mathrm{~cm}$ in diameter. Similar results were obtained by Tuovinen et al. (2009) in Finland with the biggest hailstone reaching $8 \mathrm{~cm}$ in diameter.

The prevailing number of the large hail cases that occurred in southern and south-eastern parts of Poland, indicate that the highland and closeness to mountain barriers may trigger large hail formation. According to Zinkiewicz and Michna (1955) proximity of water reservoirs may also affect the frequency of hail as they become a significant water vapor supplier. This may explain the large number of severe hailstorms across the Masurian Lakeland in the analyzed year. The importance of orography as a major contributor to the development and intensification of the hail production was also mentioned by Sioutas et al. (2009) and Kunz et al. (2009).

When it comes to the synoptic conditions, most of the large hail events during 2012 were associated with cold fronts and squall lines, usually with the south-western warm and moist air mass influx. The most severe cases of hail were recorded on the $3^{\text {rd }}$ July 2012, when highly unstable atmosphere with CAPE values reaching $2880 \mathrm{~J} \mathrm{~kg}^{-1}$ and significant amount of water vapor in the boundary layer covered S and SE part of the country. CAPE index was also used by Siou- tas and Flocas (2003) for the analysis of the hail events in Northern Greece. Values indicating hailstorms in that region ranged on average between 1001 and $2500 \mathrm{~J} \mathrm{~kg}^{-1}$ with $18 \%$ of situations when they exceeded $2500 \mathrm{~J} \mathrm{~kg}^{-1}$.

The collision of tropical highly unstable warm and moist air masses with much cooler polar maritime ones within a cold front resulted on the $3^{\text {rd }}$ July 2012 in the formation of the mesoscale convective system (MCS). The most destructive hailstones $(\sim 7 \mathrm{~cm}$ in diameter) were found near Czechowice-Dziedzice around 1600 UTC.

\section{Acknowledgements}

This research was supported by the Grant for Scientific Research of National Science Centre: N/ ST10/04780 ("The influence of the atmospheric circulation on the occurrence of hail in Poland and selected countries of the Central Europe in the years 1971-2010"), project leader: Katarzyna Suwała, carried out at Adam Mickiewicz University. Supportive and useful comments by an anonymous reviewer were also appreciated.

\section{References}

Bielec-Bąkowska Z., 2002. Zróżnicowanie przestrzenne i zmienność wieloletnia występowania burz w Polsce 1949-1998, Wydawnictwo Uniwersytetu Śląskiego.

Bielec-Bąkowska Z., 2010. Występowanie gradu w Polsce w świetle cyrkulacji atmosfery w latach 1966-2006. In: T. Ciupa, R. Suligowski (eds), Woda w badaniach geograficznych. Kielce: 359-374.

Browning K.A., 1964. Airflow and precipitation trajectories within severe local storms which travel to the right of the winds. Journal of the Atmospheric Sciences 22: 664-668.

Changnon S.A., Changnon D., Hilberg S.D., 2009. Hailstorms across the nation. An atlas about hail and its damages, Illinois State Water Survey.

Cotton W.R., van den Heever S., Jirak I., 2003. Conceptual Models of Mesoscale Convective Systems: Part 9. Colorado State University.

Craven J.P., Brooks H.E., 2004. Baseline climatology of sounding derived parameters associated with deep moist convection. National Weather Digest 28: 13-24.

Dessens H., 1960. Severe hailstorms are associated with very strong winds between 6000 and 12,000 meters. Physics of Precipitation, Geophysical Monograph, Washington, D.C., American Geophysical 5: 333-338.

Doswell III C.A., Burgess D.W., 1993. Tornadoes and tornadic storms: a review of conceptual models. In: H. Church et al. (ed.), The Tornado: Its Structure, Dynamics, Prediction, and Hazards. American Geophysical. Union 79: 161-172.

Dotzek N., Groenemeijer P.H., Feuerstein B., Holzer A.M., 2009. Overview of ESSL's severe convective storms re- 
search using the European Severe Weather Database ESWD. Atmospheric Research 93: 575-586.

Folland C.K., T.R. Karl, J.R. Christy, R.A. Clarke, G.V. Gruza, J. Jouzel, M.E. Mann, J. Oerlemans, M.J. Salinger and S.-W. Wang, 2001. Observed Climate Variability and Change. In: Climate Change 2001: The Scientific Basis. Contribution of Working Group I to the Third Assessment Report of the Intergovernmental Panel on Climate Change. Cambridge University Press, Cambridge, United Kingdom and New York, NY, USA.

Galway J.G., 1956. The lifted index as a predictor of latent instability, Bulletin of American Meteorological Society 37: 528-529.

Groenemeijer P.H., Dotzek N., Stel F., Brooks H.E., Doswell C.A., Elsom D.M., Giaiotti D.B., Gilbert A., Holzer A.M., Meaden G.T., Salek M., Teittinen J., 2004. A data format for severe weather events to be used in Europe. 3rd European Conference on Severe Storms, León, Spain, 9-12 Nov.

Groenemeijer P.H., van Delden A., 2007. Sounding-derived parameters associated with large hail and tornadoes in the Netherlands. Atmospheric Research 83: 473-487.

Hart J.A., Korotky W., 1991. The SHARP workstation v1.50 users guide. National Weather Service, NOAA, U.S. Departmentof Commerce: 30 pp. [Available from NWS Eastern Region Headquarters, 630 Johnson Ave., Bohemia, NY 11716].

Knight C. A., Knight N.C., 2001. Hailstorms. In Severe Convective Storms. In: American Meteorological Society Doswell III (ed.), AMS Monograph 28(50): 223-254.

Kolendowicz L., 2006. The influence of synoptic situations on the occurrence of days with 294 thunderstorms during a year in the territory of Poland. International Journal of Climatology 26: 1803-1820.
Koźmiński Cz., 1964. Geograficzne rozmieszczenie większych burz gradowych zanotowanych na obszarze Polski w latach 1946-1956. Przegląd Geograficzny 36: 87-102.

Kunz M., Sander J., Kottmeier Ch., 2009. Recent trends of thunderstorm and hailstorm frequency and their relation to atmospheric characteristics in southwest Germany, International Journal 29: 2283-2297.

Miller R.C, 1967. Notes on analysis and severe storm forecasting procedures of the Military Weather Warning Center. Technical Report 200, AWS, USAF.

Morel C., Senesi S., 2002. A climatology of mesoscale convective systems over Europe using satellite infrared imagery. II: Characteristics of European mesoscale convective systems, Quarterly Journal of the Royal Meteorological Society 128(584): 1973-1995.

Sioutas M.V., Flocas H.A., 2003. Hailstorms in Northern Greece: synoptic patterns and thermodynamic environment. Theoretical and Applied Climatology 75: 189-202.

Sioutas M.V., Meaden T., Webb J.D.C., 2009. Hail frequency and intensity in northern Greece. Atmospheric Research 93: 526-533.

Suwala K., 2012. The influence of atmospheric circulation on the occurrence of hail in the North German Lowlands. Theoretical and Applied Climatology. 112(3-4): 363-373.

Taszarek M., Kolendowicz L., 2013. Sounding-derived parameters associated with tornado occurrence in Poland and Universal Tornadic Index. Atmospheric Research 134: 186-197.

Tuovinen J.-P., Punkka A.-J., Rauhala J. Hohti H., Schultz D.M., 2009. Climatology of Severe Hail in Finland: 19302006, Monthly Weather Review 137(7): 2238-2249.

Zinkiewicz W., Michna E., 1955. Częstość występowania gradu w woj. lubelskim w zależności od warunków fizjograficznych. Annales UMCS, Sectio B, 10(5): 224-267. 